\title{
A POSTCOLONIAL BIOGRAPHY OF SADRACH The Tragic Story of an Indigenous Missionary
}

\section{Emanuel Gerrit Singgih}

The Theological Faculty, Duta Wacana Christian University;

Indonesian Consortium for Religious Studies, Yogyakarta, Indonesia email: gerrit@staff.ukdw.ac.id

\section{Abstract}

Nowadays, many Indonesian Christians are fully aware that evangelic mission in Indonesian context is to be involved in the dialogue of life with one's neighbor and share their struggles. Sadrach, an indigenous missionary who lived in $19^{\text {th }}$ century, can be seen as a pioneer in this mission method. However, this method was not accepted by the foreign missionaries at that time. They accused Sadrach's method as a form of syncretism. This work is an attempt to analyze Sadrach's biography in the framework of postcolonial theory which argues that Indonesian Christians have to learn about their colonial past and strive to maintain equal relationships with non-Indonesian Christians. It is hoped that his achievements can be appreciated by the present generation, and they will not repeat the mistakes of the past. It is also good to be aware that resistance to Sadrach's mission nowadays will come from some contemporary international mission-bodies which continue the old way of propagating Christian faith without regard to the context of Indonesia.

[Banyak orang Kristen sekarang ini sadar bahwa misi dalam konteks Indonesia adalah melibatkan diri dalam dialog kebidupan dengan sesama dan ambil bagian dalam pergumulannya. Sadrach, seorang penginjil lokal yang bidup pada abad ke-19 dapat dianggap sebagai salah satu pelopor metode misionaris seperti ini. Akan tetapi penyebaran misi ala Sadrach ini tidak diterima oleh para misionaris asing. Upaya seperti ini dianggap sebagai sinkretisme. Tulisan ini merupakan studi biografi Sadrach dalam kerangka teori poskolonial yang bertujuan untuk menunjukekan peranan Sadrach dalam penyebaran misi Injil di Indonesia. Diharapkan generasi sekarang 
akan belajar dari dan tidak mengulangi kesalahan-kesalahan masa lampau. Studi ini juga untuk menyadarkan babwa perlawanan terbadap model misi Sadrach pada masa kini akan muncul dari badan-badan misi internasional yang tetap menjadi model-model misi Kristen yang tidak, memedulikan konteks Indonesia sama sekali.]

Keywords: Sadrach, indigenous missionaries, foreign (Dutch) missionaries, colonial policy, independent christians.

\section{A. Introduction}

On the night of 1 October 1967, several church buildings, Christian/Catholic schools and pastors'/priests' residences in the city of Ujung Pandang (now Makassar) were ransacked by Muslims. They were incensed by reports that a teacher of Christian religion at a state senior high school (SMA I at Bawakaraeng Street) had given derogatory remarks on the conduct of the prophet Muhammad saw. This particular incident could be seen as the climax of tensions between Muslim and Christian communities in Indonesia after the change of the political situation in October 1965, following the unsuccessful coup d'etat of September 30, 1965. ${ }^{1}$ To ease the tensions, the government took the initiative to hold a national Musyawarah Antar Umat Beragama (a national inter-religious consultation) in Jakarta on 30 November 1967. On this occasion, President Soeharto and the minister of religious affairs, M. Dahlan, pleaded for the recovery of good relationships and reminded the representatives that religious propagation should not raise conflict among adherents. For this reason the adherents of one religion should not be made the target of the propagation of other religions. The Christian delegation could not accept this plea, as that could mean the end of mission and evangelism as well as the Islamic dakwah. As a result the consultation failed and it contributed to the worsening relationships of the two religions. ${ }^{2}$

Does the situation remain the same, almost fifty years after the consultation? If one reads Jan Aritonang's magisterial Sejarah Perjumpaan Kristen dan Islam di Indonesia, then the impression is that in every period of the encounters (six periods from the arrival of the Portuguese

1 Jan Sihar Aritonang, Sejarah Perjumpaan Kristen dan Islam di Indonesia (Jakarta: BPK Gunung Mulia, 2010), p. 383.

2 Jan Sihar Aritonang and Karel A. Steenbrink, A History of Christianity in Indonesia (Leiden: Brill, 2008), pp. 207-8. 
conquistadores to the "Reformation" era), the dominant character of the encounter is always of conflict. Aritonang seems to be pessimistic, if not realistic. That is why in the concluding chapter he asks whether there is still hope for betterment of the relationships. ${ }^{3}$ If so then there is no significant progress from the Musyawarah up to the "Reformation" era.

Steenbrink, however, is more optimistic, although not overtly so. Although he agrees that the Musyawarah is a disappointment to both Muslims and Christians, it encourages both sides to have deeper acquaintanceship, knowledge and understanding of each other, and it became a starting point for further consultation and dialogue. ${ }^{4}$ Eventually this inter-religious relationship, or better, Muslim-Christian relationship, resulted in a more generally positive climate, although from 1999-2002, in the eastern part of the country, the situation regressed to become communal clashes. Another factor could be added, namely the awareness of pluralism, which, although not without opposition, becomes more accepted. Formerly it was seen in the context of ethnicity, but now it is broadened to include plurality of religions. In the context of Indonesia, Christianity and Islam are facts that have to be acknowledged and appreciated reciprocally.

Many Indonesian Christians are now aware that missionary attempt to introduce and witness to Christian faith has to pay utmost attention to the feelings of those who are addressed to. As such, mission could only mean to involve oneself in dialogue of life with one's neighbor and share their struggles. While this new type is considered as the result of the development of inter-religious relationship which started in the second half of the $20^{\text {th }}$ century, not many are aware that in the second half of the $19^{\text {th }}$ century there were already attempts to do mission in a different way from what was usually done by foreign missionaries. ${ }^{5}$ Sadrach, an indigenous missionary, was the foremost one, who can be seen as one of the pioneers in mission as sharing neighborly life with other members of the Javanese society.

There are at least two books concerning Sadrach's method of

3 Aritonang, Sejarab Perjumpaan, p. 383.

${ }^{4}$ K.A. Steenbrink, "Patterns of Muslim-Christian Dialogue in Indonesia, 19651978" in Muslim-Christian Perception of Dialogue Today: Experience and Expectations, ed. by Jacques Waardenburg (Leuven: Peeters, 2000), p. 84.

${ }^{5}$ It is telling that the supposedly standard work of Indonesian Church History refers in passing (in only two pages) to Sadrach but do not regard him an embodiment of new kind of mission, see Jan Sihar Aritonang and Karel A. Steenbrink, A History of Christianity in Indonesia (Leiden: Brill, 2008), pp. 674-5. 
evangelic mission, Sadrach's Community and Its Contextual Roots by Sutarman and Mission at the Crossroads by Sumartana. Sutarman thinks that the present Javanese churches should continue to tread in Kyai Sadrach's steps. Sumartana is in favor of "syncretism", but not according to the understanding of the Javanese Christians. ${ }^{6}$

This work tries to analyze Sadrach's biography from postcolonial perspective. ${ }^{7}$ Postcolonial reading means, among others, how we as Indonesian Christians who were once colonized and missionized by others, learn about colonial past and strive to maintain equal relationships with non-Indonesian Christians who live in the Northern Hemisphere in this era of globalization, the descendants of former colonizers, who belong to the same denomination as us. ${ }^{8}$ By studying Sadrach's biography, it is hoped that his achievements can be appreciated by the present generation, and by using the word 'tragic' in the title of this paper, it is also hoped that the present generation will not repeat the mistakes of the past, and be aware that resistance to Sadrach's kind of mission nowadays, which is a contextual mission, will come from some contemporary missionbodies which are continuing the old way of propagating Christian faith without regard to the context of Indonesia.

\section{B. Sadrach's Youth and Baptism}

Sadrach's original name is Radin. He was born near Demak in 1835, at the north coast of Central Java. He comes from a family of poor farmers, and it was not unusual for a member of the family to leave and wander around to seek a better life. At the same time, there was at that time a custom for young people to make some journey (lelana brata), looking for someone older in order to be led to achieve wisdom (ngelmu). Perhaps these two motives are mixed, as to become a disciple with a guru (kyai) and staying with him together with other aspirants provide a regular life. At least there is a place to sleep and to eat. Sadrach did not rest with one guru, but had several. He moved from one place to another. He

${ }^{6}$ Th Sumartana, Mission at the Crossroads: Indigenous Churches, European Missionaries, Islamic Association and Socio-religious Change in Java, 1812-1936 (Jakarta: BPK Gunung Mulia, 1994).

7 See Philip Holden, "Postcolonial auto/biography", in The Cambridge History of Postcolonial Literature, ed. by Ato Quayson (Cambridge: Cambridge University Press, 2012), pp. 107-36.

8 See Elizabeth Mudimbe-Boyi, "Missionary Writing and Postcolonialism", in The Cambridge History of Postcolonial Literature, ed. by Ato Quayson (Cambridge: Cambridge University Press, 2012), pp. 81-106. 
journeyed to Mojowarno in East Java. Mojowarno is a Christian village, established by Javanese Christians. But this first meeting did not have any effect on Sadrach. He did not decide to become a Christian and join the Mojowarno Christians. From Mojowarno he moved to Ponorogo at the border between East Java and Central Java, and then again moved to Semarang at the north coast, and chose to live in the 'Kauman' area, where the observing Muslims usually stay. Here he added the name 'Abas' to his name, to show that he too, belongs to the observant Muslims. Later on, still in Semarang, he met a Christian guru, Kyai Tunggul Wulung, who worked in the area around Northern Central Java (the Muria area). This guru organized Christians to build a cluster of villages, in the same way the East Javanese Christians had been doing. The largest among these villages is Bondo.

In 1866 Radin Abas went to Batavia (now Jakarta) to meet a Dutch lawyer, retired high government official and a lay Christian, Anthing. This lawyer is very keen in matters of Evangelization. Eventually he became one of Anthing's assistant. It was in Batavia that Radin decided to let himself be baptized. He was baptized on April 14, 1867 in an old church (The 'Sion' Portuguese buitenkerk church) which belonged to the colonial state church. He took the name Sadrach, one of the three Jews who faced trial by fire in the book of Daniel, chapter 3, as his Christian name. According to a biographer of Sadrach, C. Guillot, the name is not chosen randomly. Just like the biblical Sadrach, who refuses to renounce his Jewish heritage under the threat of the mighty ruler of Babel, so now "the Javanese Sadrach" will also refuse to renounce his Javanese identity under the threat of the Dutch colonial rulers and their religion. ${ }^{9}$ Then why was he baptized in a colonial church? I think Guillot was trying to draw an image of Sadrach as a revolutionary Javanese who is anti-Dutch in every aspect. It seems, however, that although Sadrach was a genuine indigenous Christian, he was not anti-Dutch per se. It was the Dutch missionaries that started to treat him as an enemy, when it was clear that he would not follow the regulations they put on him.

\section{From an Assistant in Batavia to Independent Work in Karangjoso}

After his baptism, Sadrach stayed for a while with Anthing and

9 Claude Guillot, Kyai Sadrach: Riwayat Kristenisasi di Jawa (Jakarta: Grafiti Pers, 1985), pp. 63-4. 
helped with colportage work. He must also be impressed with Anthing's method of evangelization, which tolerated many indigenous customs. For instance, Anthing taught his disciples the Lord's Prayer, which according to him is like a Javanese mantra which could protect them from dangers. But then he moved back to Semarang, and then to Bondo, the headquarters of Kyai Tunggul Wulung, until 1869. Tunggul Wulung, the founder of Bondo, did not settle in Bondo until 1875 (the title Kyai is honorific, and is usually related to the person as a religious teacher). During his absence, he was represented by Pak Sis, and in turn Pak Sis was assisted by Sadrach. When Tunggul Wulung visited Bondo and stayed for a while, Sadrach decided to leave Bondo. No reason was offered of his leave. According to the Dutch missionaries, Sadrach wanted to gain influence in Bondo, and eventually aspired to replace Tunggul Wulung as the village head, but he failed. According to other sources, the reason is the decision of Tunggul Wulung to take a second wife, as it was the custom of many village heads of that period. That may be a strong reason as Sadrach was known as an observant Christian (before that he was an observant Muslim), and although he takes inspiration from local culture and is regarded by many as a pioneer of contextualization, all his life he regarded Christianity as a set of teachings, or better, rules (pranatan) which has to be observed in detail, including monogamy. ${ }^{10}$

Another reason, and this is the strongest one, is the feeling of having received a vocation from God (wangsit) to go to a place which is still unknown to him, like the call of God to Abraham to leave Ur and place himself in the hand of God. ${ }^{11}$ Sadrach wandered again for one year, first going to East Java, to Mojowarno, but in the end of 1869 he went back to Central Java and settled down at Purworejo, in a village called Tuksongo. Here he met a Eurasian couple, Mr. and Mrs. Philips-Stevens and Mrs. Van Oostrom-Philips. Mr. Philips was a supervisor at an indigo plantation. Mrs. Philips-Stevens and Mrs. Van Oostrom-Philips were also very active in evangelization, and succeeded in gathering small groups in their respective houses. ${ }^{12}$ Although they already had two assistants

${ }^{10}$ Alle Gabe Hoekema, Denken in Dynamisch Evenwicht: De Wordingsgeschiedenis Van De Nationale Protestantse Theologie in Indonesië (ca. 1860-1960) (Zoetermeer: Boekencentrum, 1994), p. 69.

${ }^{11}$ Guillot, Kiai Sadrach, p. 67; Sutarman Soediman Partonadi, Sadrach's Community and Its Contextual Roots: A Nineteenth Century Javanese Expression of Christianity (Amsterdam: Rodopi, 1988), p. 67.

12 Th Sumartana, Mission at the Crossroads: Indigenous Churches, European Missionaries, Islamic Association and Socio-religious Change in Java, 1812-1936 Jakarta: BPK Gunung 372 Al-Jämi'ah, Vol. 53, No. 2, 2015 M/1437 H 
(Abisai and Tarub), they accepted Sadrach to become their third assistant. With his Javanese style of evangelization, Sadrach was very successful in adding the number of people who gather at the homes of the Philips ladies. Soon he overshadowed the other two assistants.

After one year he moved to another village, Karangjoso, near Kutoarjo. This village is destined to become the basis of Sadrach's work. His relationship with Philips ladies continued, and mainly through the help of Mrs. Philips-Stevens, people who wanted to be baptized were introduced to the minister of the Indische church (the colonial state church) in Purworejo. Sadrach continued his unique Javanese way of preaching the Gospel, namely by holding debates with ngelmu gurus. It is common to regard the Javanese as people who tend to look for consensus in a quiet way, in accordance to the principle of harmony in society. They are thought of abhorring arguments or debates. But in very important matters, such as truth claim, they do not hesitate to use powerful arguments. These debates between gurus of wisdom are held in a dignified way, and those whose arguments are stilled, are expected to become disciples of the one who won the debate. If a guru becomes a Christian, his disciples automatically followed their guru and also become Christians.

Eventually Sadrach settled in Karangjoso. Karangjoso is different from Mojowarno and Bondo, which are built as Christian villages. But such is the prestige of Sadrach as a ngelmu guru, that the villagers accepted him as their foremost member. Like Tunggul Wulung, he was also called "Kyai". They rely on him for instance, when they want to decide the safety of a certain plant to be used as medicine, or they asked him to pray before they open a space in the forest which is usually regarded as haunted by evil spirits, but the followers of Tunggul Wulung, Anthing and Sadrach have a prayer to neutralize poison and combat evil powers which sounded like this:

"O Allah, Father, Son and the Holy Spirit, we beseech Thee to neutralize the dangerous poison from these plants so that they may be used for our benefit; also render the inhabitants of this forest powerless, so that the land may be utilized for the village. May the blessing of the Lord Jesus Christ, and His peace be upon us all, Amen". ${ }^{13}$

Mulia, 1994), pp. 19-20.

13 Partonadi, Sadrach's Community and Its Contextual Roots, p. 67. 
When the number of Christians in Karangjoso increased, they decided to build a church. It was built in the Javanese style, and was called a "mosque". The style is indeed commonly associated with mosques. The building was finished in 1871, since that they did not need to go to Tuksongo for the Sunday worship. Mrs Philips-Stevens was still formally the leader of these indigenous Christians, but the real leader was Sadrach. At one time his followers reached 7552, compared with the followers of the missionaries, which in fifty-years of hard work, never reached the figure of $2000 .{ }^{14}$

What are the factors that make the non-Christian people of Karangjoso accept Sadrach as one of their own, and even accept him as the foremost head of the community? It is his reliance on the cultural context, namely the Javanese-Hindu-Muslim heritage which becomes part of the religious life of both Javanese Muslims and Christians. To see how the workings of this reliance, it is good to see how the Christians of Karangjoso perform their rituals. It goes without saying that rituals are one of the means of identification, which makes one group aware of their differences from the others. However, the Christians of Karangjoso did not live apart from their neighbors, but lived alongside their neighbors, and such, from outward appearances, their rituals were not very different from their neighbors'. Sutarman Partonadi describes the Christian rituals in detail and compares them with the rituals of the Javanese Muslims. ${ }^{15}$ There are rituals of marriage, rituals concerning pregnancy, childbirth and circumcision, rituals concerning death, rituals concerning land cultivation and farming, New Year celebrations, and other miscellaneous rituals. All these rituals are performed by paying attention to its similarities with the customs of the whole community. For instance, the community performed the ritual of circumcision. It is not placed in antithesis to baptism, as in the teachings of the missionaries. While the missionaries were opposed to circumcision as an obsolete Jewish ritual which has been superseded by baptism and view the Muslim circumcision as a continuation of this superseded ritual, the Sadrach's community regards it as an important Javanese custom and thus it was never abolished. ${ }^{16}$ The community also celebrated New Year, but not the western New Year. Along with their Muslim neighbors, the Christian community celebrated Lebaran. The rituals of death are not very different
${ }^{14}$ Ibid., pp. 94, 102, 129.
15 Ibid., pp. 145-52.
16 Ibid., p. 147. 
from the Muslim rituals of death, and the same holds for the other rituals. But there are also customs which are not celebrated by the community, for instance, slametan to honor the spirit of the dead, rituals concerning the month of Sura and rituals which are closely related to the life of the Prophet Muhammad saw. ${ }^{17}$ Partonadi's commented that the effort of the members of Sadrach's community to christianize the Javanese Muslim rituals is impressive. They made a noble attempt to remain within their Javanese heritage without denying their new faith. It could be added that because of this achievement, the Christian community of Karangjoso were accepted within the larger community of the Javanese Muslims.

This progress on the side of Sadrach is at the same time the reason for resentment and enmity of the Dutch missionaries (from the De Nederlandsche Gereformeerde Zendings Vereniging, NGZV; Eng: 'The Dutch Reformed Mission Organization' and later from the Zending van de Gereformeerde Kerken in Nederland, ZGKN; Eng: 'Mission of the Reformed Churches in the Netherlands') and of the Indische church congregation at Purworejo. This emotion can only be explained as coming from a background of colonial mentality. I have stated above that Sadrach is not anti-Dutch. He has good relationships with Anthing and the Philips couple. But the missionary policy at that time always insisted that leadership and initiative has to come from the side of the Dutch missionaries and not from the indigenous Christians. In the framework of colonial mentality, the indigenous Christians must be put under the control of the foreign missionaries. If they refuse it, then the missionaries have to take action against them. Since 1873 Mrs Philips-Stevens was often in a sickly condition, and died in 1876. Sadrach then was regarded by the indigenous community as the formal leader in the area of Bagelen. At that time he was just 40. He got married, and as it was the custom of many Javanese, he added to his name, another name, Suropranoto. This marriage was childless, but Sadrach has an adopted son, Yotham, who later inherited his mantle. The Dutch missionaries became more agitated in regard to Sadrach's position as a leader, and start to insinuate the colonial government to become suspicious of Sadrach. In 1882 the head of the local government, W. Ligtvoet formally accused Sadrach of preventing the government's program of smallpox vaccination, and Sadrach was held for three weeks in detention at the prison of Kutoarjo, and after that he was placed at "house arrest" for three months at the house of P. Bieger, the missionary who was appointed by Ligtvoet to 17 Ibid., p. 151. 


\section{Emanuel Gerrit Singgih}

replace Sadrach as the leader of the congregation. But in the end he was released on the orders of the Governor General because the evidences against him are not convincing.

Sadrach was indeed against the smallpox (Jav: cacar) vaccination, but not because of political reasons but because of religious, or biblical reasons. He followed literally the text of II Corinthians 6:3 and I Timothy 5:6-7 in the Javanese version of the New Testament. The Javanese rendering of II Cor 6:3, "no fault", is aja dicela, while in I Tim 5:6-7, "without reproach", is ajana cacad. The Javanese Bible translation of cela and cacad were literally interpreted by Sadrach as "scar". ${ }^{18}$ Smallpox vaccination at that period would often leave ugly scars on one's body, and according to Sadrach, this is contrary to the Bible as the Teachings of God. Ironically, Bieger himself actually objected to vaccination for religious reasons. He believed that one should not avoid disaster from God. ${ }^{19}$ But such was the colonial policy at that time, that Sadrach as an indigenous person could be put in prison, while Bieger as a Dutch person, could go unharmed, and even get support from the local government to replace Sadrach. F. van Lith SJ, a Jesuit priest who worked at Muntilan at the same period and later became famous for his openness to Javanese culture, was an interested spectator of this conflict. When he returned to the Netherlands for health reasons from 1921 to 1924, he wrote a treatise on Sadrach, based on the books of F. Lion-Cachet (which is anti Sadrach) and L. Adriaanse (which is pro Sadrach). Van Lith is of course pro Sadrach, and gave cynical comments on how Bieger regarded his "victory" over Sadrach. After his appointment, Bieger gathered the congregation and preached to them on the basis of a biblical text: " $M i j$ is alle macht gegeven in de hemel en op aarde" (to me is given all the powers in heaven and on earth). Van Lith did not refer to which text, but it is clearly from Matthew 28:18, part of the Great Commission, which to many at that time (and also in the present) was Jesus' only commission for his disciples. In his report to the mission board in the Netherlands, Bieger saw his "victory" as the workings of the hands of God. But this is too much for van Lith, and he commented loudly in his treatise: "Bieger! Bieger! Bieger! Hoe geweldig heb je je vergist! Gij hebt gedacht de Geest Gods in Uw hart te voelen en het was uw eigen menselijke geest' (Bieger! Bieger! Bieger! How enormously you are in the wrong! You think that you feel the Spirit

${ }^{18}$ Hoekema, Denken in Dynamisch Evenwicht, p. 68; Partonadi, Sadrach's Community and Its Contextual Roots, pp. 74-5.

19 Partonadi, Sadrach's Community and Its Contextual Roots, p. 75. 
of God in your heart, while it is your own human spirit). ${ }^{20}$

This sad incident is sufficient to give us a picture on the policy of the missionaries, who did not hesitate to use the arm of the government to harm their fellow Christians (albeit indigenous) who prefer to live independently of them. There are also reports that for a considerable time worship in the church at Karangjoso was prohibited by the police. ${ }^{21}$ On the other hand, it also clear, that the local colonial government did not hesitate in interfering in religious disputes or conflicts, despite the official neutrality of the Central Colonial Government. The only Dutch missionary at that period who could understand the vocation of Sadrach is rev. J. Wilhelm. His view is an exception from the general attitude of the missionaries. In his diary he commented on the detention of Sadrach as a grave mistake. Sadrach was innocent, it was the Dutch who were in the wrong. Relationship between Wilhelm and Sadrach was very good, and Sadrach even asked Wilhelm to become a leader of the worship services in Karangjoso. Wilhelm accepted this request, and was rewarded with angry comments by his colleagues. The congregation which was led by Wilhelm called themselves golongane wong Kristen kang mardika ("the group of independent Christians") and Wilhelm called himself pandita mardika ("an independent minister"). The word mardika originated from the Malay term, merdeka, "independence, freedom" and Sutarman is of the opinion that this term was suggested by Wilhelm, who was familiar with the idea of freedom in the West. ${ }^{22}$ Although Wilhelm was a member of the mission board which sent him to Central Java, in this occasion he did not regard himself as a representative of the mission board. He did not act as the superior of Sadrach, but regard Sadrach as an equal partner. Sadrach ministered in his Javanese way, Wilhelm with his Western way. Rather than confronting each other, they precisely complement each other. In this period a picture was taken of this two strange bedfellows (later it becomes very famous, or notorious, depending of one's point of view), in which they were shown as sitting on chairs and at the same level.

This is indeed something unusual, as it was the custom of that period that even in the missionary circles, whenever there is a mixed encounter, only Dutch people sit on chairs, while the Javanese Christians,

${ }^{20}$ Franciscus van Lith, "Kjahi Sadrach: Eene les voor ons uit de Protestantsche Zending van Midden-Java”, Typewritten Manuscript, The Library of Kolese Santo Ignation, Yogyakarta (1937), p. 24.

21 Guillot, Kiai Sadrach, p. 115.

22 Partonadi, Sadrach's Community and Its Contextual Roots, p. 78. 
even if they are evangelists, had to sit on the floor or stand behind the sitting figures. In Dutch circles the photo which shows Wilhelm and Sadrach sitting on chairs was interpreted theologically as a sign that Wilhelm has opened the door for syncretism. He was accused as sitting together with Balaam. But then they comforted themselves: we do not have to worry, even if Wilhelm did this thing, Jesus would not sit beside Baal. ${ }^{23}$ Wilhelm had to endure many insults. In the end he left the congregation and perhaps because of inner struggle to face the pressure, he became ill and died in 1892. His diary was discovered by his successor, L. Adriaanse, who arrived in 1895 from the Netherlands. Later on he wrote a book based on Wilhelm's diary to correct the negative conclusions taken by F. Lion-Cachet, a minister who was sent by the mission board of NGZV and the General Synod of the Nederduitsche Gereformeerde Kerken (NGK), Eng: 'The Netherlands Reformed Church') to investigate and report on Sadrach. Only once he met Sadrach and engaged him in light conversation, but his report is full of accusations (from others) which were written in a convincing style on the 'sins' of Sadrach. On the other hand, according to Sumartana, even the sympathetic Adriaanse did not want to acknowledge openly Sadrach's leadership over the Karangjoso congregation. ${ }^{24}$

\section{Accusations against Sadrach}

The main critic of the Dutch toward Sadrach is of a nontheological factor: they are unable to accept that Sadrach places himself in a par with them. Then it is understandable that the photo which shows Sadrach sitting together with Wilhelm functions as kerosene poured on fire. The problem really is, "sitting together on chairs at the same level or not". After that, theological arguments are constructed to pinpoint the teachings of Sadrach as syncretism, which distorts the purity of the teachings of Christianity. The accusations involved both his personality and his teachings. Concerning his personality, he is accused of thirsting for power. Because he is highly regarded by his fellow Javanese in his position as a ngelmu guru, he is thought to aspire to replace the place of Jesus Christ as the center of the congregation. The addition of the

${ }^{23}$ Ibid., p. 227. "Balaam" may refer to Bileam, a hapless Moabite prophet made famous by his talking donkey in the book Numbers chapter 22-24, or a wrong spelling of Ba'alim, which in Hebrew is a plural form of Ba'al, "the false god" of the Canaanites [EGS].

24 Sumartana, Mission at the Crossroads, p. 66. 
name "Suropranoto" is misunderstood as an attempt to uplift oneself in a position which is even higher than the Javanese kings. The honor and respect shown by his followers are regarded as a demand from the side of Sadrach, and this kind of honor is often superfluous, e.g., to kiss his feet. $^{25}$ This superior feeling is related to Sadrach's position as a ngelmu guru. How could such a position be reconciled with an evangelist?

From the point of view of the missionaries, the honor bestowed to Sadrach is of course superfluous. But that is normal for the traditional Javanese cultural phenomenon from that period. A ngelmu guru was regarded as an example (panutan) in searching for wisdom, and that is why he is honored. But it depends on the concrete, everyday life of the guru. The minute he becomes conceited and demands to be honored, he will lose the trust of his disciples. They will desert him, and look for another guru. This is a paradox in the everyday life of the Javanese people up to this day, which people like Lion-Cachet sorely missed. Also the ignorance towards the life style of a Javanese is shown in the way LionCachet translated Sadrach's new name Suropranoto. Actually it means, "Him who has the courage in ordering". But Lion-Cachet translated suro as "god". Suropranoto thus means, "A god who rules". This meaning will never enter into the mind of a normal, ordinary Javanese, as many Javanese from the lower strata also use the term suro in their names. And for a Christian Javanese, the position of Sadrach as a ngelmu guru and an evangelist is not regarded as incompatible, in the same way that Kyai Tunggul Wulung from Bondo is also regarded as guru and evangelist. Of course, if ngelmu is regarded in a narrow way as an art of manipulating spiritual powers in order to achieve one's self-interest, as 'magic', then ngelmu is incompatible with the Gospel.

Ngelmu is not just magic, but broader than that. It is related to the understanding of a Javanese person concerning wisdom, on how one see himself/herself in the midst of the whole reality, on searching and making of harmony, on salvation and perfection of life. In short, ngelmu is a process of discovering the self-understanding of a Javanese concerning his place or existence in the universe, where he/she comes from, where he/she is now and where is he/she going to. The Gospel is not the same as ngelmu, but is there no possibility to understand ngelmu or to use the approach of ngelmu as an effort to find the truth of the Gospel, not unlike the parable of the man who was looking for a buried treasure in the Gospel, who decided to do this thing, i.e. to sell

25 Guillot, Kiai Sadrach, p. 158. 
everything he has (ngelmu), in order that he can buy the land and thus acquire the buried treasure, or the parable of someone who is looking for a precious pearl, and also sell everything he has to be able to buy the precious pearl? Ngelmu is not only a worldview, but also a way of life. That is why the figure of a guru becomes important as an example (panutan). In looking at the exemplary figure, the disciple can be able to discern the truth, and decide for himself/herself what way to choose to achieve wisdom. Through the figure of the guru, religion becomes concrete in praxis. At the time of Sadrach, most of the missionaries held the narrow understanding of ngelmu. If we do cultural analysis towards the view of these missionaries, then it is clear that this narrow view reflected a negative outlook at the local culture as a 'low' culture, compared with the culture of the missionaries. But there are also exceptions. We have seen Wilhelm above, and according to Sutarman, there are also a few other missionaries who tried to understand ngelmu in a broader way. ${ }^{26}$

The most interesting objection of the missionaries is the teaching of Sadrach on the person of Jesus Christ as Ratu Adil (The Just King/ Ruler), or by using Sutarman's term, Sadrach's Christology. Not only that, sometimes the insinuation points to Sadrach, who regarded himself as the awaited Ratu Adil, Christ within the figure of Sadrach. The latter stressed that Jesus comes to the unjust world to establish his kingdom, and this kingdom is the kingdom of justice. According to the missionaries, Sadrach misunderstood the Gospel. The kingdom of God is not worldly or revolutionary, but spiritual and eternal. Believers enter the kingdom of God as the result of accepting salvation from Jesus Christ, and such life in the kingdom of God is to be understood as pointing at the future and even out of this world, the kingdom of God as a heavenly kingdom. Jesus comes to the world to offer salvation so that humankind may enter the heavenly kingdom of God. This other-worldly aspect of the kingdom of God is of course compatible with the colonial framework of thought. Sadrach's idea of the kingdom of God then was thought of having political implications, and for the colonial rulers, this implications is dangerous. In other contexts, there are missionaries who support the independence movements, but in the context of Java in the middle of the $19^{\text {th }}$ century, almost all of the missionaries adhered to the colonial policy. Although the Sadrach congregation at Karangjoso used the term mardika (independent), contrary to Guillot, it seems that their understandings of the term are not yet political. What they emphasized is their independence

26 Partonadi, Sadrach's Community and Its Contextual Roots, pp. 192-7. 
in choosing how to live as Christians. But of course from the side of the missionaries, this emphasis is seen as political. ${ }^{27}$ They are afraid that this independent position will give raise to political aspirations.

\section{E. Sadrach's Conversion to the Apostolic Church and his Death}

The Dutch missionaries of Central Java then launched a systematic campaign to purge the Javanese congregations from indigenous thinking and isolate Sadrach at Karangjoso. But even so, there are still efforts to convince him to cooperate with them. Adriaanse, who became sympathetic to Sadrach, thinks that a friendly attitude towards Sadrach will bring good results. But as we have seen above, the problem is not of friendly relationship, but of equal relationship, and concerning this matter, Sadrach is obstinate until his death. On the other hand the constant pressure from the missionaries tires him. He can no longer request individuals from the missionary circle to minister baptism or Holy Communion. Although Sadrach is head of the community, he is not an ordained minister. On the one hand he rejected the missionary structure, but on the other hand he still has high respect on the validity of ordination. When it was clear that the missionaries would not ordain him unless he placed himself under their jurisdiction, he then looked for other solution, which he find in the Apostolic church. His old mentor in Batavia, Anthing, has joined the Apostolic church and was ordained as an apostle. It is not difficult to imagine that Anthing suggested to Sadrach to contact the nearest Apostolic community. And so, Sadrach made contact with the Apostolic church at Magelang which was led by the apostle Liem Cu Kiem.

This community is the result of the mission of the Apostolic church, which can trace their root to the Irvingian Apostolic church in England. According to van Lith, who for several weeks joined their Sunday morning worship at Bintaru, the color of their faith is eschatological or apocalyptic: the sermons are almost always about the book of Revelation and so they are close to the Adventists. On the other hand, they worship on Sunday (not Saturday), and do not incorporate teachings of the Old Testament concerning unclean food. Probably this interest in eschatology corresponds to the faith of the Javanese Christians on the coming of Ratu

27 See Emmanuel Gerrit Singgih, "Mengkaji Ulang Makna Sinkretisme", in Berteologi dalam Konteks: Pemikiran-Pemikiran Mengenai Kontekstualisasi Teologi di Indonesia (Jakarta; Yogyakarta: BPK Gunung Mulia; Kanisius, 2000), p. 105. 
Adil, ${ }^{28}$ but Sadrach's eschatology is directed to the future of the world, while the Apostolic Church focuses on otherworldly. In this church the office of the apostle is still recognized, and it is not difficult to imagine that they offered this office to Sadrach, with the hope that he will become a member of the Apostolic Church with his followers (now about 8000).

In 1899 Sadrach went to Batavia again, and was ordained as an apostle by G.J. Hannibals, who represented the Dutch Apostolic Church in Batavia. ${ }^{29}$ It is not clear why Sadrach has to go to Batavia for his ordination and not just receive his ordination from Liem $\mathrm{Cu}$ Kiem at Magelang. Maybe he suspected that his community will be placed under the authority of the Magelang community. When he returned to Karangjoso, this ordination was celebrated with Holy Communion, and he himself presided over the service. ${ }^{30}$ At that time he was 64. With his new title of "apostle" (he was even regarded as "the apostle of/for Java"), Sadrach became more energetic in consolidating and developing his followers. Nominally they belong to the Apostolic Church, but in reality the Karangjoso congregation follows "new ngelmu", i.e. the contextualized Christianity of Sadrach. With his title as an apostle, he did not seek to preserve his relationship with the Dutch, who still try to contact him and so they broke. The church under the Dutch missionaries and the church of Sadrach went their own way. He was given a strong constitution, and led his church until he died quietly at his home next to the "mosque", at the old age of 89 in 1924.

\section{F. Concluding Remarks}

Sadrach was succeeded by Yotham, his adopted son, but Yotham was not a strong figure. When the Dutch missionaries re-opened contact with Karangjoso after the death of Sadrach, he was open to it, and eventually led his congregation back to the folds of the missionaries. This happened in 1933 and that time Sadrach's congregation consisted between 10.00020.000 members. ${ }^{31}$ Is there a social reason for this return? At the end of the $19^{\text {th }}$ century the colonial government launched the hated program of Culturrstelsel, which is a forced-planting policy. In the beginning of the $20^{\text {th }}$ century the situation of Central Java was very difficult. Reports from the missionaries were full of stories of hardships and sufferings

28 Lith, "Kjahi Sadrach", p. 75.

29 Partonadi, Sadrach's Community and Its Contextual Roots, p. 92.

${ }^{30}$ Ibid.

31 Ibid., p. 129. 
of the people. Actions done to ease their plight were met with positive reaction. The missionaries changed their strategy from verbal to social ministry. This social ministry in the field of health, education and welfare attracted the people of Java, and even the followers of Sadrach returned to the care of the missionaries. According to Sumartana, who studied the aftermath of the struggle between Sadrach and the missionaries, the Sadrach community was not prepared to face this challenge of social needs of the people. For Sumartana this points to the main weakness of the indigenous movement. Sumartana's analysis gives the impression that it was not Kyai Sadrach who won the field as it was often summarized, but it was the Dutch missionaries. ${ }^{32}$ It seems that the failure of the contextualization movement to respond to the sufferings of the people leads Sumartana to differ from the conclusions of Sutarman, who in his dissertation thinks that the present Javanese churches should continue to tread in Kyai Sadrach's steps. In his dissertation Sumartana is in favor of "syncretism", but not according to the understanding of the Javanese Christians, but, accordingly, to its "original" meaning, that is, political meaning. ${ }^{33}$ For Sumartana, in the present it is wrong to continue to cling to the missionaries' Gereformeerd (Dutch Reformed) teachings. However, it is equally wrong to continue Sadrach's teachings. On the other hand, because the Javanese church has inherited the paraphernalia of social ministry from the Dutch missionaries, they ought to preserve social ministry and makes it relevant to meet the challenges of the present.

When the Karangjoso church became part of the missionary church, every vestiges of the teachings of Sadrach were erased. For a long period, even after the Javanese Christian Church became independent from the missionaries in 1934, there is a fierce antagonism from the side of the church towards signs of revival of Javanese Christianity. Every attempt to introduce cultural dimensions to the life of the congregations is met with alarm cries of syncretism. What is about Sumartana's conclusions above? I disagree with Sumartana's conclusion that it is wrong to develop contextualization in cultural matters. Sadrach's indigenous theology, especially his Christology, is a starting point to express the essential freedom of human beings. Culturally speaking, it is traditional, but we should not reject everything that is traditional. If we reject tradition, it could be that we are rejecting ourselves, and overvalue other expressions of culture. If we are doing that, then (this is the lesson of Sadrach) we

32 Sumartana, Mission at the Crossroads, pp. 59-107.

33 Ibid., pp. 337-40. 


\section{Emanuel Gerrit Singgih}

will lose our freedom. Sadrach did not return to ngelmu and sacrifice the Gospel, as he was often accused. He started from ngelmu, and hold on to the Gospel. This indigenous Christology has a social content or message, which could be meaningful in a context of local culture. It seems that Sumartana wanted to say that the missionaries won the struggle because they started to use modern technology, which is available to them, in the framework of social ministry as a strategy. Sadrach's community was also practicing social ministry, albeit in a traditional way. This is described in detail by Sutarman in his dissertation. ${ }^{34}$ Probably, this is their weakness. However, if the present Javanese Christian Church really want to continue in the footsteps of Sadrach as advised by Sutarman, then it must not reject its cultural context. It has to look for relevant ways to practice this social ministry as advised by Sumartana, but the context should be always based on local culture.

Now there is awareness that Sadrach was neglected for a long time. In the weekly service of Karangjoso church nowadays, however, nothing of contextualized theology can be noticed. People tend to flock to his grave, to do pilgrimage. After his death Sadrach became more or less a wali, and many, especially non-Christians come to pray at his grave. This practice of pilgrimage is frowned upon by the church-officials, but they can do nothing, as Sadrach does not belong to them. He belongs to the people. The Apostolic Church' small congregations still exist in central Java, but also no trace of Sadrach's teaching is evident. So in the end, the story of Sadrach is a tragic story. But it must be told again and again, so that we at the present time do not repeat the mistakes.

Grand narratives on Muslim-Christian relationship in Indonesia may produce a pessimistic view on the possibility of peaceful coexistence, but local narratives such as the story of Sadrach could produce a more optimistic view. Sadrach's way of contextualization should be continued even for the present Christian generation, albeit not in details. We have seen above that contextualization paves the way for harmonious and irenic relationship with the majority Muslim community. From the observations on the irenic interaction of a Christian community with their Muslim neighbors, and the role of Sadrach in creating this irenic atmosphere, it is also interesting to ask how Sadrach is seen from the side of the Muslim scholars. As far as I know there are no articles on Sadrach, written by Muslim scholars. If there were such writings, then the result could have been a balanced inter-cultural or inter-faith view on

${ }^{34}$ Partonadi, Sadrach's Community and Its Contextual Roots, pp. 161-2. 
A Postcolonial Biography of Sadrach an important historical figure, which is sorely needed by both Christians and Muslims. 